\title{
Chapter 12 \\ China and the BRI: Challenges and Opportunities for Southeast Asia
}

\author{
Alessandro Albana and Antonio Fiori
}

\begin{abstract}
Since Xi Jinping's unveiling, in 2013, the Belt and Road Initiative (BRI) has drawn remarkable global attention, raising polarized judgements about China's ambitions. A number of countries and institutions enthusiastically considered the BRI as a valuable infrastructural and economic contribution that would enhance connectivity among Eurasian countries; on the other hand, critics viewed the BRI as part of Beijing's effort to gain global influence, especially within its neighborhood. Chinese policymakers have considered Southeast Asia as a critical region for the success of the BRI, mainly because of the geographical proximity as well as the strong economic ties with both individual states and the ASEAN. In Southeast Asian states' view, however, the BRI still presents a mixed picture of opportunities and challenges. Despite the clear appeal the BRI has to both democratic and authoritarian leaders in the region, especially at a time of economic uncertainty-fueled by unhelpful actions by the United States (withdrawal from the TPP and the trade war against Beijing)—concerns remain. Potential overdependence on China, the BRI's financial sustainability and negative popular perceptions about Beijing within certain Southeast Asian countries, all contribute to nurture caution in the region. The paper aims at showing how the implementation of the BRI will likely enhance China's influence in Southeast Asia. Against this backdrop, whereas the establishment of a renovated Sinocentric system is far from certain, this study sheds light on the challenges and opportunities the BRI is determining upon Southeast Asian countries and their relationship with Beijing.
\end{abstract}

This article reflects the joint outcome of the efforts of both authors. In practice, though, AA wrote the sections "Introduction" and "Southeast Asia and the BRI: A Chinese Perspective," whereas AF wrote the sections "The Unraveling of the BRI in Southeast Asia" and "A Long Way Ahead for the BRI."

We are aware it may sound quite odd, but it is required by the Italian Agency for the Evaluation of the Academic System and Research (ANVUR) for co-authored articles to be eligible for evaluation. For this reason, it is important that the footnote be included.

\footnotetext{
A. Albana (凶)

Asia Institute, Bologna, Italy

e-mail: alessandro.albana2@unibo.it
}

\author{
A. Fiori \\ University of Bologna, Bologna, Italy
}

(C) The Author(s), under exclusive license to Springer Nature Singapore Pte Ltd. 2021 


\section{Introduction}

In late 2013, the President of the People's Republic of China (PRC) and General Secretary of the Chinese Communist Party (CCP) Xi Jinping officially unveiled the One Belt One Road (OBOR), an ambitious international project aimed at developing an integrated network of infrastructural, financial and trade connections between China and Central, South and Southeast Asia, Oceania, the Middle East, East Africa and Europe. In September that year, Xi Jinping gave a speech at Nazarbayev University, in Kazakhstan, during which he introduced the "Silk Road Economic Belt", OBOR's overland leg (Ministry of Foreign Affairs of the PRC, 2013). The following month, during a visit to the Indonesian Parliament, Xi introduced the " 21 st Century Maritime Silk Road", the maritime projection of the Belt and Road Initiative (BRI, as the OBOR had later been rebranded) connecting China's eastern coast to the Indian Ocean region, the South Pacific Ocean and even the Mediterranean region (Xinhua, 2013). The contexts where the project was announced are meaningful for the understanding of the global significance of the BRI. Central Asia, where Kazakhstan lays as the biggest post-Soviet state whose record of economic and political relations with China has been on the rise since the collapse of the USSR, holds crucial importance for the implementation of the BRI overland projects. Concurrently, Indonesia, and Southeast Asia more broadly, is crucial for the implementation of the Maritime Silk Road (MSR), as China's relations with the region are characterized by robust economic ties but have failed to achieve positive and longstanding momentum in the political and diplomatic realm. Southeast Asian nations seem to have generally welcomed the BRI, which could provide great opportunities to enhance regional trade-a pivotal factor for ASEAN countries after the collapse of the Trans-Pacific Partnership (TPP) - through the improvement of interregional connectivity. The BRI could be highly beneficial in endowing Southeast Asia with infrastructure greatly needed by some of these countries, unleashing the full economic potential of the region. In our contribution, we aim at showing how the implementation of the BRI will likely enhance China's influence in Southeast Asia. Against this backdrop, this study sheds light on the challenges and opportunities the BRI is determining upon Southeast Asian countries and their relationship with Beijing.

\section{Southeast Asia and the BRI: A Chinese Perspective}

In order to discern the importance of Southeast Asia for China's BRI, it is necessary to understand how and why such a gigantic and-to some extent-hazardous project has come to be seen as a foreign policy priority by the Chinese leadership. As China's foreign policy represents a comprehensive, proactive and complex dimension for the implementation of Beijing's global strategic vision, this study frames the BRI as a landmark initiative whose significance is not limited to economic or diplomatic considerations, being rather all-encompassing (Callahan, 2016). Against 
this backdrop, it has been widely emphasized that, with Xi Jinping becoming the top leader of the CCP (2012) and the PRC (2013), China's foreign policy shifted to a more proactive, let alone assertive, approach (Zhang, 2015). The unveiling of the BRI, occurring few months after Xi took office, well epitomizes the shift from President Deng Xiaoping's call for "keeping a low profile" (taoguang yanghui 蹈光养 晦) in global affairs - a prescription endorsed at a later stage by Deng's successors, Jiang Zemin and Hu Jintao-to "striving for achievement" (yousuo zouwei 有所作 为) (Yan, 2014b; Zhou \& Esteban, 2018). From this perspective, the BRI signals China's increasing self-confidence, with the Chinese leadership seemingly growing progressively convinced that sustained economic growth, incremental military capabilities and rising diplomatic influence at the international level made Beijing ready to play a greater role in global affairs (Yu, 2017).

From a different perspective, the BRI may also be understood as a strategy aimed at addressing the emergence of critical phenomena affecting China's domestic economy and foreign relations. Several negative factors may have supported Chinese leaders' decision to embark on such an ambitious initiative. Firstly, China's GDP growth has been cooling since the second half of 2014, falling from a double-digit growth to between 6 and 7 percent on a yearly basis, ushering in a "New Normal" of "slower but more sustainable economic development" (Zhang \& Chen, 2017, p. 1). Secondly, one of the top economic priorities for the Chinese government is to solve the massive excess capacity in several productive sectors, such as steel and cement; in fact, this overcapacity is at the foundation of several difficulties, such as increasing debt levels and squeezing corporate profits, contributing to making the domestic financial system more vulnerable. The BRI, with its focus on infrastructural oeuvres, represents a source of alleviation to the Chinese industrial overcapacity, promotes the internationalization of the Chinese currency, stimulates the country's economic growth, assists the transition from investment-led growth to a consumer-driven economy and, especially in Southeast Asia, it supports developing countries affected by significant infrastructural deficits. Thirdly, the reorientation of the US strategic vision announced by the Obama administration in late 2011, known as the "Pivot to Asia", provoked disquiet within the Chinese leadership, as the shift in Washington's foreign policy was perceived as an attempt to enhance the US influence in the Asia-Pacific region, with obvious detrimental implications for China's rise (Shambaugh, 2013; Wang, 2016). Fourthly, China seemed to be growing increasingly concerned with the deterioration of its relations with Southeast Asian countries in the wake of the 2008 financial crisis (Wang, 2016). Whereas economic ties between China and its Southeast Asian neighbors have increased steadily from 1997 through 2016-with Beijing-ASEAN bilateral commercial exchanges jumping from USD 24,2 billion to USD 460,3 billion (Laurenceson, 2017)_political relations were yet to overcome widespread concerns from Southeast Asian countries towards China's interests in the region. In particular, Beijing's assertive stance regarding maritime disputes in the South China Sea (SCS), where also Malaysia, the Philippines, Taiwan, Vietnam and-to a lesser extentBrunei Darussalam maintain overlapping claims, has contributed a great deal to the Southeast Asian nations' mistrust of China. Finally, China is highly dependent on the Strait of Malacca, a chokepoint controlled by Indonesia, Malaysia and Singapore, 
through which about 80 percent of its energy needs flows. For China, it would be vital to control the Strait of Malacca through the MSR in order to safeguard its economic and energy security from being threatened by other countries and escape from the entrapment represented by the so-called "Malacca Dilemma" (Shi, 2004).

Under such circumstances, in the eyes of the Chinese leadership it was seemingly clear that economic engagement alone might have not been sufficient for enabling broader political convergence with the region. Not surprisingly, the early announcements of the BRI in 2013 were soon to be followed by President Xi's call for the shaping of a "Community of Shared Destiny" (gongtong mingyun $t i$ 命运 共同体) (Xi, 2017). Whereas such a strategic vision potentially involves the entire international community, it is at Southeast Asian countries that it is first and foremost targeted. Tellingly, the Community of Shared Destiny was first called upon during President Xi's speech in Indonesia in 2013 (Xinhua, 2013). During that year, moreover, Premier Li Keqiang "emphasized the need to build the Maritime Silk Road oriented towards ASEAN" within the framework of the China-ASEAN Expo (NDRC, Ministry of Foreign Affairs \& Ministry of Commerce of the PRC, 2015).

Enjoying geographical proximity and longstanding cultural, economic and political relations with Beijing, Southeast Asia has traditionally represented a crucial dimension for the implementation of the BRI, if only for its proximity to China and its location at the juncture between East Asia, Oceania and the Indian Ocean region (Callahan, 2016). The development of the project has therefore been accompanied by a number of cultural, economic and political initiatives promoted by Beijing and aimed at consolidating ties with the region in a comprehensive fashion. Against this backdrop, the Community of Shared Destiny can be considered as China's strategy to enhance economic exchanges, pursue better diplomatic relations, and improve people-to-people connections with Southeast Asian nations. In this scenario, Beijing does not only seek to improve international cooperation with the region, but rather pursues a more comprehensive strategy nurturing a wider political understanding based on the principle of win-win cooperation.

That the Community of Shared Destiny is to find its core in Southeast Asia is further epitomized by the unveiling of the "Peripheral Diplomacy" (zhoubian waijiao 周边外交). Significantly, both the Community of Shared Destiny and the Peripheral Diplomacy have been announced in 2013; as far as broad strategic objectives are concerned, moreover, both dimensions seem to have much in common. As with the Community of Shared Destiny, the Peripheral Diplomacy defines a comprehensive set of actions aimed at "integrat[ing] domestic and international goals [...], comprehensively expanding from economic engagement to foster closer political, cultural and security networks" (Callahan, 2016, p. 5). Against this backdrop, the Peripheral Diplomacy and the Community of Shared Destiny can be conceived as integrated and intertwining strategies aiming at the consolidation of China's influence in Southeast Asia as much as at the improvement of China's domestic development (Yan, 2014a). Indeed, while announcing the "Chinese Dream of National Rejuvenation", President Xi made clear that the Peripheral Diplomacy had to play a key role for the achievement of the Chinese Dream (Xi, 2017). The Chinese Dream (Zhongguo meng 中 国梦) sets two “centennial goals" for the PRC to become a moderately prosperous 
country by 2021 (100th anniversary of the CCP foundation) and an "affluent, strong, civilized and harmonious socialist modern country" by the 100th anniversary of the establishment of the PRC, in 2049 (Xinhua, 2012). Whereas its exact meaning may be subject to many and different interpretations, the Chinese Dream came to epitomize Xi Jinping's strategic vision for an economically prosperous, socially stable, politically strong and globally proactive China in the twenty-first century.

China's ambition for a comprehensive engagement of Southeast Asia can be seen as both one of the key objectives and a necessary precondition for the implementation of the BRI. That such an engagement is pursued in a comprehensive fashion is further demonstrated by the involvement of Southeast Asian nations in a broader range of international initiatives, such as the Asian Infrastructure Investment Bank (AIIB). Beginning operations in January 2016, the AIIB emerged as a multilateral development bank investing mostly in the infrastructure sector. Established by China, the AIIB has been joined by all Southeast Asian countries, looming as a key tool in Chinese hands for shaping the Community of Shared Destiny in the region (Ren, 2016). In this scenario, the BRI connectivity pursued by Beijing is emerging in terms of hardware infrastructure while also focusing on the consolidation of soft connections between China and Southeast Asia (Callahan, 2016; Yu, 2017). Clearly, China nurtures high hopes for the BRI's success in Southeast Asia, and the initiative holds the potential to make China "the dominant force in determining the future economic landscape of Southeast Asia" (Gong, 2019; Yu, 2017, p. 120).

\section{The Unraveling of the BRI in Southeast Asia}

If, during the Cold War, Southeast Asia looked at China with diffidence, considering it as a threat, the situation gradually changed in the wake of Beijing's transition to a market economy: in the 1990s, in fact, major powers in the region started to normalize their relations and establish institutionalized connections with the PRC. One of the most appreciated gestures was the financial assistance granted by China during the Asian financial crisis, in 1997 and 1998: Beijing's refusal to devalue the renminbi impressed Southeast Asian countries, which admired China as a responsible power that respected their interests. This move, along with the inconsistency of the International Monetary Fund and the World Bank in dealing with the crisis, accelerated the establishment of the "ASEAN Plus Three" mechanism: the exclusion of the United States, interpreted as a decline of Washington in the region, was highly welcomed by China, who seized the opportunity to maximize its influence in the area (Cheng, 2013). Thereafter, despite tensions re-merging periodically, largely due to the SCS disputes, Sino-ASEAN relations have gradually improved, to the point that in 2002 a Framework Agreement on Comprehensive Economic Co-operation was signed to establish a free trade area (FTA) covering the six old ASEAN nations by 2010 and all ten ASEAN members by 2015. Since the launch of the FTA, China's share of ASEAN total merchandise trade increased from 8 percent in 2004 to 21 percent in 2018; since 2009, China has become ASEAN's biggest trade partner, 
with trade volume amounting to USD 591.1 billion in 2018 (Menon \& Melendez, 2019a). In addition, in 2017 China has become ASEAN's third-largest source of FDI, with flows amounting to USD 11.3 billion (Menon \& Melendez, 2019b). Along with trade and investment, China has become one of the most important sources of economic development assistance and infrastructural development to the region. The relationship, however, has not only positive sides: China's claims of almost the entire area of the SCS, in spite of the revendications of Southeast Asian coastal states, have sparked tensions, especially in the last decade, when Beijing made increasingly bold assertions as to its maritime rights in the area.

It has become habitual to divide ASEAN countries into three subgroups, depending on their different approach to the BRI. The first is represented by those lowincome and most capital-needy countries, such as Cambodia, Laos and Myanmar, who are geographically pivotal for China's ambitions (Myanmar, for instance, is particularly relevant for China to decrease its dependency on the Strait of Malacca), have no territorial disputes with Beijing and have shown almost no reserves towards the BRI. Being these countries in need of infrastructure that can contribute to the enhancement of local economies, their cooperation with Beijing has promptly developed; some examples of that cooperation are the China-Myanmar Economic Corridor that will connect Kunming to Myanmar's major economic centers, Mandalay and Yangon, and then westward to the Kyaukpyu special economic zone in the Rakhine state; the China-Laos Railway, one of the most important constructions under the BRI, expected to be completed by 2021, that will link China's Yunnan province directly to Thailand, Malaysia and ultimately Singapore, enabling the shipment of Chinese goods to these markets avoiding long shipping routes; the Sihanoukville Special Economic Zone and the planned Phnom Penh-Sihanoukville Expressway that will improve interconnections between Cambodia's capital city and the southern provinces of the country. It must be highlighted, however, that these countries have recently proven to be more cautious towards Chinese investments, fearing the risk of an excessive debt burden. Nonetheless, since attracting investments has become extremely difficult for both Cambodia and Myanmar, due to sanctions enacted by the West over human rights abuses and other violations, they seem to have no other choice but to rely on Beijing's support for infrastructural development. Although the government-to-government relations between Beijing and these three countries appear substantially idyllic, the influx of Chinese money and people-workers and businessmen, but also tourists - is affecting the lives of locals, causing rising dissatisfaction. Many within the local communities are disappointed by the fact that small local businesses have not benefitted from the BRI-given that the money injected from China has been apparently kept within the Chinese community-and by the apparent worsening in the gap between the rich and the poor in their societies. In addition, China's increasing political influence on local communities and national authorities is often considered an existential threat to their cultures, values, and environment.

Countries in the second group, namely Singapore, Thailand and Vietnam, have been more diffident and cautious with respect to the implementation of the BRI, due to their somewhat problematic political, economic and strategic relations with 
Beijing. Hanoi, for example, is in desperate need for infrastructure investments and hence it supports the initiative diplomatically; however, the strict criteria related to the BRI loans and, above all, concerns regarding the SCS dispute have contributed to create some reluctancy. The same problem has emerged with Bangkok, with which Beijing has discussed since 2010 of the construction of a high-speed rail intended to connect Thailand's east coast ports and industrial zones to Kunming stretching through neighboring Laos. The long negotiation has been triggered by the political instability into which Thailand has been recently trapped and by the shareholding structure and interest rate on the loan China has offered (Thongnoi, 2019). The troublesome negotiations and the slow pace of the whole process were, according to some commentators, the main reason for Thai Prime Minister Prayut's exclusion from the BRI Summit held in Beijing in May 2017. China intended to show openly its dissatisfaction and use the stick rather than the carrot, but remained open to offer Thailand a second chance that took shape during the 9th BRICS Summit in Xiamen in September 2017 (Busbarat, 2017). Another crucial absence at the BRI Summit in 2017 was that of Singaporean Prime Minister Lee Hsien Loong, most likely due to the city-state's refusal to side with China in the SCS territorial dispute; later that year, however, Singaporean Premier's visit to China re-fueled mutual relations. Singapore's importance for the development of the BRI is not merely geographic, but is rather dependent to a large extent on its assessment as a financial hub and as a source of third-country partnership (Singapore Institute of International Affairs (SIIA), 2018). Nevertheless, Singapore's measured interest in the BRI is likely to continue due to its status of developed country not in need of incentives for infrastructural development, unlike poorer countries such as Cambodia or Laos.

The last subgroup involves Indonesia, Malaysia and the Philippines, i.e. countries that have shown their "Sinoskepticism" towards the BRI and its investments. Although its location in the western Pacific Ocean is critical to the MSR, the Philippines has not yet reached a single agreement on the BRI with Beijing: on some accounts, this is due to the dispute in the SCS and to the 2016 arbitration case, invoked by the former Aquino III administration, that ended up with the rejection of Chinese claims in the area (Li \& Amer, 2018). Since President Duterte's election, in 2016, bilateral relations have intensified and improved, as demonstrated by Duterte's participation in the BRI Forum in 2017 and by President Xi Jinping's visit to Manila in November 2018, in the occasion of which 29 agreements on infrastructural projects were ratified. Even though relations between China and Indonesia are generally strong, the implementation of the BRI in that country has encountered major obstacles, because of the long consultation process that has delayed the realization of many projects, as happened with the Jakarta-Bandung High-Speed Rail (Lai, 2019). The project was hindered by permit problems, since only half of the total land needed had been secured, and by funding difficulties on the Indonesian side. In addition, Jakarta is keen on ensuring that BRI-linked projects employ local workforce. President Jokowi's reelection in 2019, however, seems to favor bilateral stability and a positive cooperation on the BRI. Finally, even though Malaysia was one of the most enthusiastic countries about the BRI, things dramatically changed in the wake of the 2018 general election, when former Prime Minister Mahathir Mohamad 
defeated Najib Razak, due to the lingering scandals in the administration but also to the country's worsening economic conditions. Mahathir voiced criticism against China's perceived "neo-colonial" style, particularly in rolling out its ambitious BRI with peculiar financing and contracts entrapping Southeast Asian nations. He also cancelled a USD 20 billion railway project — the East Coast Rail Link-funded by China, assuming that his country would be unable to provide financial contribution to its realization. At present, however, not only the project has re-materialized and the cost has been cut by one-third, but Malaysians are also publicly supporting the BRI and encouraging Beijing to make more investments, particularly in less developed areas along the planned railway route.

\section{A Long Way Ahead for the BRI}

Over the past year, the competition between China and the United States, which has become more intense in the trade sector, has been carefully-and somewhat apprehensively_scrutinized by Southeast Asian countries. Since late 2017, in fact, the region has become the most important "battlefield" in the tug-of-war between China's "Community of Shared Destiny" - epitomized by the BRI — and the Free and Open Indo-Pacific (FOIP) strategy, launched by US President Donald Trump. The FOIP strategy not only depicts China as a strategic competitor that aims to achieve "Indo-Pacific regional hegemony", but also warns Southeast Asia against China's predatory intentions with regards to economics and military modernization. If, on one side, Washington's condemnation aims at countering China's aggressive behavior, especially in the SCS, on the other hand it is a very hazardous posture: despite the American economic engagement continues to be strong in Southeast Asia - the US exports about USD 75 billion in goods and USD 31 billion in services to ASEAN countries annually, and ASEAN has received approximately USD 329 billion in cumulative FDI from Washington (Stromseth, 2019)—China's economic leverage is incommensurably bigger, in spite of the uneasiness provoked in countries like Malaysia by Beijing's rising economic influence. Therefore, although most ASEAN countries deeply appreciate the US commitment to regional security and its expanding defense engagement, they seem to be growing increasingly fascinated by what Beijing can offer. After all, many countries in the Southeast suspect that, unlike his predecessor, President Trump is snubbing them, as demonstrated by his decision not to attend the ASEAN meetings (apart from the 2017 event, when he left early and skipped the East Asia summit). The dissatisfaction with the US delegation-including Ambassador O'Brien, not a cabinet member, and Secretary of Commerce Wilbur Ross - at the 2019 East Asia Summit pushed ASEAN leaders to downgrade their representation at the recent 7th ASEAN-US Summit in Bangkok, where only Laotian, Thai and Vietnamese heads of state showed up, while the seven other member states simply sent representatives, in a move that has been considered a rebuke to Washington. If coupled with the decision taken at the beginning of his presidency in 2016 to pull the US out of the TPP, which the Obama administration had 
fought hard to negotiate, it may appear likely that Trump is not giving the Southeast Asian chessboard the importance it deserves.

With a total estimated value of over USD 1 trillion, the BRI is an ambitious effort to strengthen infrastructure, trade, and investment links between China and the rest of the world, and Southeast Asian nations look at it with interest. However, one of the gravest endangerments all Southeast Asian countries have denounced is the possibility that the region falls into the "China debt trap" in the context of the BRI (Yamada \& Palma, 2018). The term implies that China extends excessive credit to a debtor country, gaining access into the country's economic and political workings when the counterpart is unable to fulfill the debt. One of the best examples of this phenomenon is represented by Sri Lanka, who, in 2017, was unable to repay the onerous debt it had accumulated to China; for this reason, Beijing was formally given a 99-year lease on the Hambantota port, a facility built by a Chinese company, funded by Chinese loans and then included into the BRI as part of a debt-reduction deal (Lim \& Mukherjee, 2018). In addition, given that-as it happens in other parts of the world, such as the African continent-China's interactions with the "target" country is limited to government-to-government relations, without any relevant involvement of local communities, some BRI projects, including the Hambantota port, are perceived as generous concessions to Beijing. For this reason, some BRIrelated projects have faced growing and fierce opposition by local communities in several countries, including Cambodia, Myanmar, Pakistan and Sri Lanka. This is also a good indicator to measure the widening trust deficit between China and many of its neighbors regarding the perceived real intentions which could be detrimental to the full implementation of the BRI. Whereas, on the Chinese side, the narrative on the BRI is focused on a win-win strategy, many of the neighbors tend to be more suspicious, deeming that the Chinese economic power and influence might determine critical political dependencies. Such concerns generate a certain degree of insecurity and anxiety: several Southeast Asian countries look at the Chinese plan to facilitate infrastructure investment with the utmost interest but, concurrently, they feel timorous of becoming too dependent on China. On top of that, even though the majority of costs needed to fuel the BRI are borne by the PRC and supported by the AIIB, the New Development Bank or the Silk Road Fund, individual countries involved in the program are still required to fund their domestic projects: this exposes exposing many Southeast Asian nations to serious financial difficulties that sometimes bring to the suspension or postponement of projects.

\section{References}

Busbarat, P. (2017). China's 'shame offensive': The omission of Thailand's Prime Minister from the belt and road initiative summit 2017. ISEAS Perspective, 54, 1-9.

Callahan, W. A. (2016). China's "Asia Dream": The belt road initiative and the new regional order. Asian Journal of Comparative Politics, 1(3), 226-243. https://doi.org/10.1177/205789111664 7806 
Cheng, J. (2013). China's regional strategy and challenges in East Asia. China Perspectives, 2013(2), 53-65. https://doi.org/10.4000/chinaperspectives.6182

Gong, X. (2019). The belt \& road initiative and China's influence in Southeast Asia. The Pacific Review, 32(4), 635-665. https://doi.org/10.1080/09512748.2018.1513950

Lai, H. (2019). Indonesia: The Belt and Road Initiative and relations with China. Retrieved February 12, 2021, from https://theasiadialogue.com/2019/10/04/belt-and-road-initiative-in-ind onesia-and-relations-with-china/

Laurenceson, J. (2017). Economics and freedom of navigation in East Asia. Australian Journal of International Affairs, 71(5), 461-473. https://doi.org/10.1080/10357718.2017.1301374

Li, J., \& Amer, R. (2018). Xi's visit to the Philippines: Implications for China-Philippine relations. Retrieved February 12 2021, from https://isdp.eu/publication/xis-visit-to-the-philippines/

Lim, D. J., \& Mukherjee, R. (2018). Does debt pay? China and the politics of investment in Sri Lanka. Retrieved February 12 2021, from https://thediplomat.com/2018/01/does-debt-pay-chinaand-the-politics-of-investment-in-sri-lanka/

Menon, J., \& Melendez, A. C. (2019a). The upgraded ASEAN-China free trade agreement: What's new, and will it matter? https://www.iseas.edu.sg/images/pdf/ASEANFocus\%20-\%20June \%202 019.pdf

Menon, J., \& Melendez, A.C. (2019b). The upgraded ASEAN-People's Republic of China free trade Agreement could matter, big time. Retrieved February 15 2021, from https://www.asiapathwaysadbi.org/2019/08/the-upgraded-asean-prc-free-trade-agreement-could-matter-big-time/

Ministry of Foreign Affairs of the PRC. (2013). President Xi Jinping delivers important speech and proposes to build a Silk Road Economic Belt with Central Asian countries. Retrieved February 15 2021, from https://www.fmprc.gov.cn/mfa_eng/topics_665678/xjpfwzysiesgjtfhshzzfh_665686/ t1076334.shtml

NDRC, Ministry of Foreign Affairs of the PRC, \& Ministry of Commerce of the PRC. (2015). Vision and actions on jointly building Belt and Road. Retrieved February 12 2021, from http:// 2017.beltandroadforum.org/english/n100/2017/0410/c22-45.html

Ren, X. (2016). China as an institution-builder: The case of the AIIB. The Pacific Review, 29(3), 435-442. https://doi.org/10.1080/09512748.2016.1154678

Shambaugh, D. (2013). Assessing the US "Pivot" to Asia. Strategic Studies Quarterly, 7(2), 10-19.

Shi，H. (2004). 能源安全遭遇“马六甲困局”中日韩能否携手? [Energy security faces the "Malacca Dilemma". Can China, Japan and Korea Cooperate?]. Retrieved February 15, 2021 from https://business.sohu.com/2004/06/15/49/article220534904.shtml

Singapore Institute of International Affairs (SIIA). (2018). Setting the record straight - Singapore's role in the BRI. Retrieved February 12, 2021 from http://www.siiaonline.org/setting-the-recordstraight-singapores-role-in-the-bri/

Stromseth, J. (2019). Don't make us choose. Southeast Asia in the throes of US-China rivalry. https:// www.brookings.edu/wp-content/uploads/2019/10/FP_20191009_dont_make_us_choose.pdf

Thongnoi, J. (2019). If China funds Thailand's high-speed rail, will the debt be too much? Retrieved February 12 2021, from https://www.scmp.com/week-asia/geopolitics/article/3007551/chinawants-fund-thailands-us12-billion-high-speed-railway

Wang, Y. (2016). Offensive for defensive: The belt and road initiative and China's new grand strategy. The Pacific Review, 29(3), 455-463. https://doi.org/10.1080/09512748.2016.1154690

$\mathrm{Xi}$, J. (2017). The governance of China. Foreign Languages Press.

Xinhua (2012). Xi Jinping pledges 'great renewal of Chinese nation'. Retrieved February 12 2021, from http://www.china.org.cn/china/2012-11/30/content_27269821.htm

Xinhua (2013). 习近平主席在印尼国会发表重要演讲[President Xi Jinping delivers an important speech at the Indonesian Parliament]. Retrieved February 15 2021, from http://www.xinhuanet. com/world/xjpynghyj/wz.htm

Yamada, G., \& Palma, S. (2018). Is China's belt and road working? A progress report from eight countries. Retrieved February 12 2021, from https://asia.nikkei.com/Spotlight/The-Big-Story/IsChina-s-Belt-and-Road-working-A-progress-report-from-eight-countries 
Yan, X. (2014a). China's new foreign policy: Not conflict but convergence of interests. Retrieved February 12 2021, from https://www.huffpost.com/entry/chinas-new-foreign-policy_b_4679 425? guccounter $=1$

Yan, X. (2014b). From keeping a low profile to striving for achievement. The Chinese Journal of International Politics, 7(2), 153-184. https://doi.org/10.1093/cjip/pou027

$\mathrm{Yu}, \mathrm{H}$. (2017). China's belt and road Initiative and its implications for Southeast Asia. Asia Policy, $24,117-122$.

Zhang, J. (2015). China's new foreign policy under Xi Jinping: Towards 'Peaceful Rise 2.0'? Global Change, Peace \& Security, 27(1), 5-19. https://doi.org/10.1080/14781158.2015.993958

Zhang, J., \& Chen, J. (2017). Introduction to China's new normal economy. Journal of Chinese Economic and Business Studies, 15, 1-4. https://doi.org/10.1080/14765284.2017.1289454

Zhou, W., \& Esteban, M. (2018). Beyond balancing: China's approach towards the Belt and Road Initiative. Journal of Contemporary China, 27(112), 487-501. https://doi.org/10.1080/10670564. 2018.1433476

Dr. Alessandro Albana is Associate Research Fellow at the Asia Institute in Bologna holds a $\mathrm{Ph} . D$. in "Global and International Studies" from the University of Bologna. He was exchange Ph.D. student at China University of Political Science and Law (Beijing, 2016-2017) and Visiting Research Fellow at China Foreign Affairs University (Beijing, March 2019). He published in the fields of Asian Studies, Political Science and International Relations. His research interests include China's domestic politics, social development and foreign policy, IR and political systems of East Asia. He collaborates with the Fudan Development Institute at Fudan University, in Shanghai.

Antonio Fiori is Associate Professor of History and Institutions of Asia at the University of Bologna and President of the Asia Institute. He has been a visiting scholar at the United International College (Zhuhai, PRC), East-West Center (Honolulu, USA), Kyujanggak Center for Korean Studies (Seoul National University, Korea), Korea University and Ewha Womans University (Seoul). He has published widely in the fields of Inter-Korean relations, North Korea's domestic and international affairs and China's foreign policy. His latest co-edited book, titled The Korean Paradox: Domestic Political Divide and Foreign Policy in South Korea, has been published by Routledge in June 2019. 